\title{
Implementasi Model Pembelajaran Berbasis Proyek untuk Meningkatkan Keterampilan Berpikir Kreatif Mahasiswa
}

\author{
Mei Indra Jayanti \\ Program Studi Pendidikan Biologi, STKIP Bima. Jalan Piere Tendean Kel. Mande Tel. Fax (0374) \\ 42801, Bima 84191, Indonesia. \\ Email: meiindra15@gmail.com
}

\begin{abstract}
Abstrak
Selama ini tuntutan kompetensi lulusan mata kuliah masih sebatas pada kemampuan mengingat dan memahami yang masih merupakan kemampuan berpikir tingkat rendah. Sedangkan kemampuan menganalisis, mengevaluasi, dan berkreasi masih belum dioptimalkan. Tujuan penelitian ini untuk mengetahui hasil implementasi model pembelajaran berbasis proyek sehingga dapat meningkatkan keterampilan berpikir kreatif mahasiswa semester VI kelas $C$ program studi pendidikan biologi STKIP Bima. Jenis penelitian yang digunakan yaitu penelitian tindakan kelas (PTK) dengan menerapkan model Pembelajarn Berbasis Proyek (PBP) selama 2 siklus. Analisis data peningkatan keterampilan berpikir kreatif dihitung menggunakan rumus gain skor (N-Gain) yang dibag dalam tiga kategori yakni rendah, sedang, dan tinggi. Hasil penelitian pada siklus I menunjukan bahwa nilai gain skor $(<g>)$ sebesar 0,154 yang berada pada kategori rendah meningkat pada siklus II menjadi 0,454 yang termasuk pada kategori sedang. Hal tersebut menunjukan bahwa implementasi model pembelajaran berbasis proyek dapat meningkatkan keterampilan berpikir kreatif mahasiswa semester VI kelas C program studi pendidikan biologi STKIP Bima.
\end{abstract}

Kata Kunci : pembelajaran berbasis proyek, keterampilan berpikir kreatif

\section{PENDAHULUAN}

Sumber daya manusia pada abad 21 dituntut untuk memiliki kualitas antara lain yaitu mampu bekerja sama, berpikir tingkat tinggi, kreatif, terampil, memahami berbagai budaya, mampu berkomunikasi, dan mampu belajar sepanjang hayat (life long leaning) (Trilling and Hood, 1999; dalam Arnyana, 2006). Berpikir kreatif merupakan konsep matang yang tumbuh dari perpaduan antara pemahaman konsep, penguatan informasi, dan eksplorasi kemampuan mencipta karya. Kegiatan tersebut tentunya didukung oleh motivasi belajar yang tinggi sehingga mampu menjadi pemicu dalam berkreasi.

Kondisi yang penulis temukan selama proses pembelajaran berlangsung di program studi pendidikan biologi STKIP Bima pada mahasiswa semester VI kelas C adalah rendahnya keterampilan berpikir kreatif mahasiswa yang diakibatkan dari rendahnya motivasi belajar dan berkarya serta minimnya tuntutan kompetensi lulusan. Ketika evaluasi hasil belajar diadakan, maka kecenderungan yang timbul adalah tugastugas yang diberikan oleh dosen hanya 
dikerjakan seadanya dan kurang mengekplorasi kemampuan berkaryanya. Mahasiswa mengumpulkan tugas tanpa memahami konten materi tugas yang diberikan oleh dosen. Padahal seyogyanya tugas dari dosen adalah sebuat bentuk pengukuran terhadap pengetahuan apa yang telah dipahami dan mampu dikembangkan oleh mahasiswa sebagai informasi yang bisa dimilikinya

Melihat kondisi di kelas tersebut, maka solusi yang bisa penulis tawarkan sebagai bentuk upaya untuk meningkatkan keterampilan berpikir kreatif mahasiswa semester VI kelas C Program Studi Pendidikan Biologi STKIP Bima adalah dengan menerapkan model pembelajaran berbasis proyek. Pembelajaran berbasis proyek adalah model pembelajaran yang menggunakan proyek/kegiatan sbagai media. Mahasiswa melakukan eksplorasi, penilaian, interpretasi, sintesis, dan pengumpulan informasi untuk menghasilkan berbagai bentuk hasil belajar. Fokus dari model pembelajaran berbasis proyek adalah pada konsep-konsep dan prinsip-prinsip utama dari suatu disiplin, melibatkan mahasiswa dalam kegiatan pemecahan masalah dan tugas-tugas bermakna lainya, memberi peluang siswa bekerja secara otonom mengkonstruk belajar mereka sendiri, dan puncaknya menghasilkan produk karya siswa
(Kamdi, 2008). Dengan serangkaian proses terintegrasi tersebut diharapkan kemamuan berpikir kreatif mahasiswa dapat meningkat.

Pembelajaran Berbasis Proyek (PBP) merupakan suatu model pembelajaran yang menyangkut pemusatan pertanyaan dan masalah yang bermakna, pemecahan masalah, pengambilan keputusan, proses pencarian berbagai sumber, pemberian kesempatan kepada anggota untuk bekerja secara kolaborasi, dan menutup dengan presentasi produk nyata (Thomas, 2000). Pembelajaran berbasis proyek ini tidak hanya mengkaji hubungan antara informasi teoritis dan praktek, tetapi juga memotivasi siswa untuk merefleksi apa yang mereka pelajari dalam pembelajaran dalam sebuah proyek nyata. Siswa dapat bekerja secara nyata, seolah-olah ada di dunia nyata yang dapat menghasilkan produk secara realistis (Purnawan, 2008). Oleh karena hakikat kerja proyek adalah kolaboratif, maka pengembangan keterampilan tersebut seyogyanya ditujukkan untuk semua tim (Marlinda, 2012). Pembelajaran Berbasis Proyek (PBP) secara umum memiliki pedoman langkah yang meliputi: Planning (perencanaan), Creating (mencipta atau implementasi), dan Processing (pengolahan) (Mahanal, 2009).

Menurut Arnyana (2006) berpikir kreatif adalah penggunaan dasar proses 
berpikir untuk mengembangkan atau menemukan ide atau hasil yang asli (orisinil), estetis, konstruktif yang berhubungan dengan pandangan, konsep, yang penekanannya ada pada aspek berpikir intuitif dan rasional khususnya dalam menggunakan informasi dan bahan untuk memunculkan atau menjelaskannya dengan perspektif asli pemikir. Parkin (1995 dalam Arnyana, 2006) mengemukakan berpikir kreatif adalah aktivitas berpikir untuk menghasilkan sesuatu yang kreatif dan orisinil.

Kemampuan berpikir kreatif terdiri dari 5 indikator, yaitu berpikir lancar, berpikir luwes, orisinal, elaborasi dan evaluasi (Rahayu, dkk, 2011). Menurut Munandar (1999 dalam Rahayu, 2011), mengajar dengan menemukan selain berkaitan dengan proses penemuan, juga bisa meningkatkan kemampuan berpikir kreatif. Karena dalam proses menemukan siswa aktif terlibat dalam situasi belajar. Siswa menyadari masalah, mengajukan pertanyaan dan menghimpun informasi sebelum mengambil keputusan, atau dengan kata lain teknik pemikiran siswa akan divergen.

\section{METODE}

Jenis penelitian ini adalah Penelitian Tindakan Kelas (PTK) dengan menerapkan model Pembelajarn Berbasis Proyek (PBP). Desain penelitian PTK kali ini menggunakan dua siklus. Tiap siklus terdiri dari tahapan planning (perencanaan), acting and observation (tindakan dan observasi), serta reflecting (refleksi). Berikut ini disajikan gambar tahapan PTK :

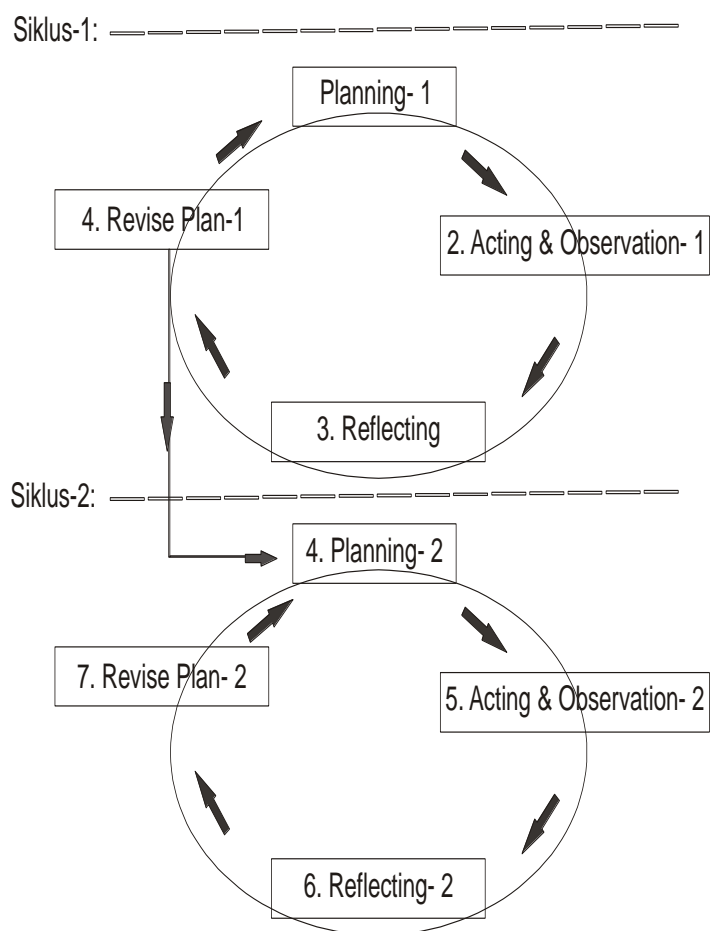

Gambar 3.1 Siklus PTK Kemmis dan Tagart (2009)

Subyek penelitian ini meliputi seluruh mahasiswa semester VI kelas C pada Program Studi Pendidikan Biologi STKIP Bima yang berjumlah 22 orang mahasiswa aktif. Instrumen yang digunakan dalam penelitian ini meliputi Lembar penilaian proyek sains (LPPS) dan soal tes keterampilan berpikir kreatif. ningkatan keterampilan berpikir kreatif dihitung menggunakan rumus gain skor (N-Gain) 
yang dikemukakan oleh Hake (2002) sebagai

berikut:

$<\mathrm{g}\rangle=\frac{(\% \text { postest }-\% \text { pretest })}{(\% \text { maks }-\% \text { pretest })}$

Keterangan:

$\langle\mathrm{g}\rangle \quad=$ gain skor

$\%$ posttest $=$ rerata nilai posttest $(\%)$

$\%$ pretest $=$ rerata nilai pretest $(\%)$

$\%$ maks $=$ nilai maksimum $(\%)$

Hasil perhitungan N-Gain lalu dikategorikan ke dalam tiga kategori seperti yang tertera pada Tabel 1.

Tabel 1 Kriteria perhitungan $\mathrm{N}$-Gain

\begin{tabular}{cc}
\hline Batasan & Kategori \\
\hline$<\mathrm{g}>>0,7$ & Tinggi \\
$0,3 \leq<\mathrm{g}>\leq 0,7$ & Sedang \\
$<\mathrm{g}><0,3$ & Randah \\
\hline
\end{tabular}

Target capaian dalam penilitian ini yakni bila nilai gain skor minimal berada pada kategori sedang $(0,3 \leq<\mathrm{g}>\leq 0,7)$. Jika pada siklus I nilai gain skor masih berada pada katerori rendah $(<\mathrm{g}><0,3)$, maka kegiatan penelitian perlu dilanjutkan ke siklus II.

\section{HASIL DAN PEMBAHASAN}

Data keterampilan berpikir kreatif mahasiswa yang dianalisis dengan menggunakan rumus gain skor $(<\mathrm{g}>)$ dapat dilihat pada Tabel 2 berikut :

\section{Tabel 2. Gain Skor $(<\mathrm{g}>)$ Keterampilan Berpikir Kreatif Mahasiswa pada Siklus I}

\begin{tabular}{ccccc}
\hline Rerata pre test & Rerata post test & Peningkatan $(\%)$ & $\langle\mathrm{g}\rangle$ & Kategori \\
\hline 23 & 34,89 & 11,89 & 0,154 & Rendah \\
\hline
\end{tabular}

Berdasarkan Tabel 2 diketahui bahwa peningkatan nilai keterampilan berpikir kreatif mahasiswa adalah $11,89 \%$ dengan nilai gain skor $(<\mathrm{g}>)$ sebesar 0,154 yang artinya masih berada pada kategori rendah $(<$ $\mathrm{g}><0,3)$. Merujuk dari hal tersebut maka diputuskan bahwa penelitian dilanjutkan ke siklus II. Sedangkan hasil analisis terhadap data keterampilan berpikir kreatif mahasiswa pada siklus II sebagai berikut :

\section{Tabel 3. Gain Skor $(<\mathrm{g}>)$ Keterampilan Berpikir Kreatif Mahasiswa pada Siklus II}

\begin{tabular}{ccccc}
\hline Rerata pre test & Rerata post test & Peningkatan $(\%)$ & $\langle\mathrm{g}\rangle$ & Kategori \\
\hline 33,89 & 57,56 & 23,67 & 0,454 & Sedang \\
\hline
\end{tabular}

Dari Tabel 3 di atas, dapat diketahui bahwa peningkatan keterampilan berpikir bahwa terdapat peningkatan nilai kreatif mahasiswa berada pada kategori keterampilan berpikir kreatif mahasiswa sedang, dengan demikian penelitian yakni 23,67\% dengan nilai gain skor $(<\mathrm{g}>)$ dihentikan sampai siklus II karena telah sebesar 0,454. Hal tersebut menunjukan 
memenuhi target minimal capaian penelitian $(0,3 \leq<\mathrm{g}>\leq 0,7)$.

Berdasarkan hasil analisis data keterampilan berpikir kreatif, diketahui bahwa terdapat peningkatan nilai gain skor dari siklus I ke siklus II. Pada siklus I, nilai gain skor yakni 0,154 yang termasuk dalam kategori rendah (Tabel 2), lalu meningkat pada siklus II menjadi 0,454 yang masuk dalam kategori sedang (Tabel 3). Peningkatan keterampilan berpikir kreatif dari kategori rendah menjadi kategori sedang menunjukana bahwa terdapat pengaruh yang positif dari imlementasi model pembelajaran berbasis proyek (PBP).

Peningkatan keterampilan berpikir kritis mahasiswa merupakan dampak positif dari penerapan model PBP yang dimana model PBP menuntut mahasiswa untuk berperan aktif dalam melaksanakan pembelajaran. Mahasiswa diminta mencari fakta, permasalahan, mengembangkan ide kreatif dan menganalisis informasi hingga manejadi satu keatuan yang utuh untuk dapat diampaikan dalam bentuk proyek sains yang tentunya tidak hanya dapat dinikmati secara visual, melaikan secara lisan maupun tertulis. Dengan rangkaian kegiatan yang memberdayakan kemampuan kognitif dan psikomotorik dari panca indera tersebut, informasi dan pengetahuan akan lebih tertanam dalam ingatan mahasiswa selaku pelaku aktif dalam pembelajaran. Mahasiswa menggali sendiri informasi untuk dirinya dan mengolah informasi tersebut sehingga mampu disampaikan kepada orang lain, tidak hanya secara verbal tetapi melalui sebuah karya kreatif yang bermakna.

Menurut Jagantara, dkk (2014), terlibatnya peserta didik secara aktif dalam kegiatan pembelajaran dengan model PBP pada hakikatnya bertujuan untuk meningkatkan motivasi, (2) kemampuan berpikir tingkat tinggi, (3) memahami materi secara menyeluruh, dan (4) meningkatkan keterampilan proses siswa. Pembelajaran biologi sangat tepat bila menerapkan model pembelajaran berbasis proyek karena memiliki beberapa kelebihan antara lain mampu meningkatkan semangat pebelajar karena pebelajar selalu aktif, membantu terciptanya suasana belajar yang kondusif karena pembelajaran bersandar pada masalah dunia nyata dan memunculkan kegembiraan dalam proses belajar mengajar. Hal ini disebabkan karena proses belajar berjalan dinamis dan terbuka dari berbagai arah.

Hasil lain yang ditunjukan dalam penelitian ini adalah meningkatnya rasa percaya diri mahasiswa saat penyajikan data di depan kelas. Hal ini dipercaya sebagai dampak dari model PBP yang mampu melibatkan siswa secara aktif dalam merancang sampai dengan menghasilkan 
produk sains. Mahasiswa cenderung memiliki rasa kepemilikan yang tinggi terhadap proyek yang dibuatnya, kepemilikan ini tidak sebatas terhadap proyek fisik yang dihasilkan, tetapi lebih dari itu yakni pengetahuan dan keterampilan baru yang dibentuk dan diasahnya sendiri. Proses konstruksi ilmu inilah yang menimbulkan motivasi dan rasa percaya diri mahasiswa. Hasil penelitian ini sejalan dengan penelitian yang dilakukan Manhal, dkk (2010) yang menunjukkan bahwa terdapat pengaruh model Problem Based Learning (Pembelajaran Berbasis Proyek) terhadap prestasi belajar kognitif dan sikap siswa terhadap ekosistem sungai. Siswa dengan PjBL mempunyai sikap yang lebih tinggi $11,65 \%$ dari siswa pada umumnya. Selain itu, siswa dengan PjBL mempunyai prestasi belajar $81,05 \%$ lebih tinggi dibandingkan dengan siswa pada umumnya.

\section{KESIMPULAN}

Berdasarkan hasil penelitian dan pembahasan, maka dapat disimpulkan bahwa implementasi model pembelajaran berbasis proyek dapat meningkatkan keterampilan berpikir kreatif mahasiswa semester VI kelas C program studi pendidikan biologi STKIP Bima dengan peningkatan gain skor dari rendah $(0,154)$ menjadi sedang $(0,454)$.

\section{DAFTAR PUSTAKA}

Arnyana, I.B.P. 2006. Pengaruh Penerapan Strategi Pembelajaran Inovatif pada Pelajaran Biologi terhadap Kemampuan Berpikir Kreatif Siswa SMA. Jurnal Pendidikan dan Pengajaran IKIP Negeri Singaraja, No. 3 TH. XXXIX Juli 2006.

Hake, R.R. 2002. Relationship of Individual student Normalized Learning Gains in Mechanics with Gender, Highschool Physics, and Pretest Scores on Mathematics and Spatial Visualization. Indiana University (Emeritus). (online) http://www.physics.indiana.edu/ h ake, diakses tanggal 19 Maret 2018.

Jagantara, I. M. W., Adnyana, P. B., Widiyanti, N. L. P. M., \& Si, S. (2014). Pengaruh Model Pembelajaran Berbasis Proyek (Project Based Learning) terhadap Hasil Belajar Biologi Ditinjau Dari Gaya Belajar Siswa SMA. Jurnal Pendidikan dan Pembelajaran IPA Indonesia, 4(1).

Kamdi, W. (2008). Project-Based Learning: Pendekatan Pembelajaran Inovatif. Pelatihan Penyusunan Bahan Ajar Guru SMP dan SMA Kota tarakan. Universitas Negeri Malang

Mahanal, S., Darmawan, E., Corebima, A. D., \& Zubaidah, S. (2010). Pengaruh Pembelajaran Project Based Learning (PjBL) pada Materi Ekosistem terhadap Sikap dan Hasil Belajar Siswa SMAN 2 Malang. BIOEDUKASI (Jurnal Pendidikan Biologi), 1(1).

Marlinda, N.L.P.M. 2012. Pengaruh Model Pembelajaran Berbasis Proyek terhadap Kemampuan Berpikir 
Kreatif dan Kinerja Ilmiah Siswa.

Tesis. Universitas Pendidikan

Ganesha.

Purnawan, 2007. Deskripsi Model PBL.

(online)

http://www.Kompas.Com.Html,

diakses pada tanggal 15 Maret 2018.

Rahayu, E., Susanto, H., Yulianti, D. 2011.

Pembelajaran Sains dengan

Pendekatan Keterampilan Proses

untuk Meningkatkan Hasil Belajar

dan Kemampuan Berpikir Kreatif

Siswa. Jurnal Pendidikan Fisika

Indonesia 7 (2011): 106-110. (online)

: https://journal.unnes.ac.id/nju/index

.php/JPFI/article/viewFile/1081/991, diakses pada tanggal 15 Maret 2018.

Thomas, J.W., 2000. A Review of Research

On Project-Based Learning. Supported by The Autodesk Foundation 111 Mclnnis Parkway San Rafael, California. (online) : http:/www.autodesk.com/foundati on, diakses pada tanggal 15 Maret 2018. 